DOI: 10.32844/2222-5374-2020-104-2.33

УДК: 342.9

Петров С. $\epsilon$,

кандидат юридичних наук, докторант

Науково-дослідного інституту публічного права

\title{
МІСЦЕ ГОЛОВНОГО СЕРВІСНОГО ЦЕНТРУ МВС УКРАЇНИ В СИСТЕМІ СУБЄКТІВ АДМІНІСТРАТИВНОГО ПРАВА
}

Актуальність статті полягає в тому, що необхідність визначення місия Головного сервісного центру в системі суб'єктів адміністративного права зумовлена потребою розподілу компетенції між органами державної виконавчої влади, визначення об'єму повноважень, необхідних для ефективного виконання поставлених перед цим органом завдань. Відсутність глибоких теоретичних розробок та керівництво виключно доцільністю створення нового органу з надання сервісних послуг в системі МBC на практиці виявило чимало проблем, в усуненні яких виникла потреба. Серед них - складність структури підпорядкування регіональних та територіальних сервісних центрів МBC, а точніше, відсутність такого підпорядкування територіальний сервісних центрів Головному сервісному центру $\mathrm{MBC}$, визначення статусу і Головного сервісного центру і Регіональних сервісних центрів як самостійних юридичних осіб публічного права ускладнило підпорядкування останнього. Спроба усунути цю прогалину шляхом визнання регіональних сервісних центрів філіями Головного сервісного центру породила ще більшу проблему у визначенні адміністративно-правового статусу територіальних сервісних центрів, яка наразі $\epsilon$ невизначеною і позиціонується як структурні підрозділи Регіональнихсервіснихцентрів МВС. У статті досліджується питаннямісия Головного сервісного центру $М В С$ в системі суб'єктів адміністративного права. Аналізуються підходи до визначення значення визначеності місия органа державної виконавчої влади в системі суб'єктів адміністративного права, та визначається ефективність обраної структури системи сервісних послуг МВС України завданням, поставленим перед Головним сервісним центром МВC. Запропоновано удосконалення такої структури та внесення змін та доповнень до Положення про Головний сервісний центр $M B C$. Визначено основні критерії та чинники, які визначають місце органу виконавчої влади, зокрема, Головного сервісного центру $М B C$ в системі суб'єктів адміністративного права. Визначено, що він є спеціалізованим органом виконавчої влади, який перебуває у підпорядкуванні Міністерства внутрішніх справ України, самостійною юридичною особою публічного права, за організаційно-правовою формою - спеціалізованим органом державної влади, який має власну компетенцію - забезпечення державної політики у сфері забезпечення безпеки дорожнього руху та безпеки експлуатації транспортних засобів, що має власну структуру: підпорядковані регіональні сервісні центри, з визначеними функціями та завданнями, та відповідними 
повноваженнями, серед яких основні: публічно-управлінські та публічносервісні, визначені Положенням про Головний сервісний центр $М B C$.

Ключові слова: територіальні сервісні центри $M B C$, компетенція, повноваження, праватаобов'язки, правоохоронніоргани, правосуб'єктність, сервісна діяльність, дозвільна діяльність, суб'єкти адміністративного права, адміністративні послуги.

Актуальність теми. Необхідність визначення місця Головного сервісного центру в системі суб'єктів адміністративного права зумовлена потребою розподілу компетенції між органами державної виконавчої влади, визначення об'єму повноважень, необхідних для ефективного виконання поставлених перед цим органом завдань. Відсутність глибоких теоретичних розробок та керівництво виключно доцільністю створення нового органу з надання сервісних послуг в системі MBC на практиці виявило чимало проблем, в усуненні яких виникла потреба. Серед них складність структури підпорядкування регіональних та територіальних сервісних центрів МBC, а точніше, відсутність такого підпорядкування територіальний сервісних центрів Головному сервісному центру MBC, визначення статусу і Головного сервісного центру і Регіональних сервісних центрів як самостійних юридичних осіб публічного права ускладнило підпорядкування останнього. Спроба усунути цю прогалину шляхом визнання регіональних сервісних центрів філіями Головного сервісного центру породила ще більшу проблему у визначенні адміністративноправового статусу територіальних сервісних центрів, яка наразі $\epsilon$ невизначеною і позиціонується як структурні підрозділи Регіональних сервісних центрів МВС. Вбачаємо, що цю проблему можна і варто вирішувати на теоретичному рівні, а вже потім втілювати ефективну модель структури органів сервісної служби МВС у життя. Таким чином, існує необхідність у визначенні кола проблемних питань місця Головного сервісного центру в системі суб'єктів адміністративного права та вирішення їх на науково обгрунтованій основі.

Стан дослідження. Певні аспекти національного правового регулювання місця окремих суб'єктів адміністративних відносин розглянуто в працях В.Б. Авер'янова, Т.О. Коломоєць, Ю.П. Битяка, Л.В. Коваля, В.С. Цимбалюка, М.В. Джафарової, О.М. Бандурки, А.Т. Комзюка, В.К. Колпакова, І.А. Мордвіна, С.В. Ківалова, Н.В. Васильєвої, В.І. Горбатюка, I.С. Сорокіна, Т.О. Булковського, Ю.П. Бурило, В.І. Гурковського.

Найбільш близькими за тематикою дослідження та визначеними питаннями $€$ праці Воронятнікова 0.0. «Адміністративно-правовий статус державної міграційної служби України» (2012) [1], Дроздової I.В. «Міністерство внутрішніх справ України, як суб'єкт надання адміністративних послуг» (2009) [2], Шуби В.В. «Адміністративно-правові відносини в діяльності органів прокуратури України: загальнотеоретичні аспекти» (2006) [3], Мельник О.М. «Адміністративно-правовий статус працівника митної служби» (2011) [4], Ізотової М.О. «Правовий статус керівника місцевої прокуратури» (2018) [5], Пустовіт О.Ю. «Адміністративно-правовий статус органів державного управління в галузі якості та безпечності сільськогосподарської продукції» (2019) [6] 
та ін. Втім, місце Головного сервісного центру MBC не було предметом їх досліджень.

Мета статті. Визначити місце Головного сервісного центру MBC в системі суб'єктів адміністративного права, визначити проблемні питання правового статусу Головного сервісного центру MBC та запропонувати їх вирішення, в т.ч. шляхом удосконалення структури підпорядкування органів сервісної служби МВС України.

Виклад основного матеріалу. Визначення адміністративноправового статусу Головного сервісного центру МВС неможливе виключно шляхом аналізу його прав, обов'язків та відповідальності. Вважаємо, що складовими його характеристики є: компетенція, повноваження, завдання та функції того органу, структурним підрозділом якого він є (МВС України), його власні, зумовлені потребою виконання саме на нього покладених завдань та місце в системі суб'єктів адміністративного права, що зумовлює характер структури правових зв'язків та правове положення у конкретному правовідношенні. Нам імпонує визначення Т.О. Мацелик, що правильне вирішення питання місця певного суб'єкта в системі суб'єктів адміністративного права впливає на предмет і метод правового регулювання, чітке визначення адресатів правових норм, обсяг їх прав і обов'язків, а також меж дії правових норм галузі та її принципів [7, с. 66].

В науці адміністративного права наразі існує, щонайменше, два підходи до визначення суб'єкта адміністративного права та суб'єктів адміністративно-правових відносин. Так, Н.В. Дараганова суб'єктами адміністративних правовідносин визначає осіб, поведінка яких підпадає під дію норм адміністративного права та визначена ними $[8$, с. 228]. Вона визнає, що такі суб'єкти наділені різними повноваженнями, структурою та юридичними властивостями. В.К. Колпаков суб'єктом адміністративного права визначив як носія (власника) прав та обов'язків у сфері публічного управління, які передбачені адміністративно-правовими нормами, здатного надані права реалізовувати, а покладені обов'язки виконувати [9, c. 73]. Т. О. Коломоєць таким визначила юридичну чи фізичну особу, що $\epsilon$ носієм прав і обов'язків у сфері державного управління, які закріплено адміністративно-правовими нормами, та таку, що має здатність надані права реалізовувати, а покладені обов'язки виконувати [10, с. 78]. Зазначимо, що в кожній галузі з цього приводу існують власні підходи. Так, представники цивільної науки, грунтуючись на положенням ст. 12 ЦК України (здійснення цивільних прав), якою визначено, що особа здійснює свої цивільні права вільно, на власний розсуд, вважають, що суб'єктивні (цивільні) права здійснюються, а реалізовуються правові норми. Ми також виходимо з таких позицій. Принаймні, він $€$ нормативно обгрунтованим. Тому вважаємо, що суб’єктом адміністративного права варто визнавати юридичну чи фізичну особу, що є носієм прав і обов'язків у сфері державного управління, які закріплено адміністративно-правовими нормами, та таку, що має здатність здійснювати надані права та виконувати права реалізовувати, а покладені на них обов'язки.

С. Г. Стеценко суб'єкта адміністративного права визначає як особу, яка має певні права та обов'язки, сформульовані в нормах адміністративного права, і може вступати в адміністративно-правові відносини $[11$, с. 91$]$. 
I.C. Гриценко визначає, що такими є фізичні та юридичні особи, які $€$ носіями прав і обов'язків у сфері публічного адміністрування [12, с. 226].

I. Литвин розмежовує суб'єктів адміністративного права та суб'єктів адміністративних правовідносин. Він $є$ прихильником першого підходу, згідно якого основним критерієм він визначив момент до вступу у відносини та факт вступу в управлінські відносини. 3 моменту вступу в відносини особи і визнаються їх учасниками, а відповідно реалізовують і правоздатність, і управлінські повноваження [13, с. 64]. Такий висновок він обгрунтовує висновками та аргументами В.В. Шуби, який визначає суб'єкта права носієм передбачених правовими нормами суб'єктивних прав та обов'язків, реалізація яких можлива в правовідносинах, а суб'єктом правовідносин - учасника реальних відносин [14, с. 81].

В. Б. Авер'янов також тримався позиції, що суб'єкт адміністративного права має лише потенційну здатність вступати у правовідносини, в той час як суб'єкт адміністративних правовідносин є фактичним носієм правових зв'язків. 3 цього він робив висновок, що суб'єкт адміністративного права $\epsilon$ «претендентом» на участь в правовідношенні, в той час як «суб'єкт адміністративних правовідносин» вже $\epsilon$ їх учасником [15, с. 95].

C. А. Новіков визначив умови набуття суб'єктом адміністративного права статусу суб'єкта адміністративних правовідносин: 1) адміністративно-правові норми, які передбачають права й обов'язки суб'єкта; 2) адміністративна правоздатність та дієздатність суб'єкта; 3) підстави виникнення, зміни та припинення правовідносин [16, с. 26].

Загалом, такий підхід є доволі цікавим, адже в такому підході автора вбачається традиційний для теорії права підхід визначення елементів механізму правового регулювання відносин. Так, Р.К. Русінов серед елементів механізму правового регулювання визначив: норми права, юридичні факти та правовідношення, а стадіями, - стадію нормативної регламентації, індивідуальної регламентації та реалізації. Притому, він визначає на стадії індивідуальної регламентації акт застосування права, індивідуалізовані владні приписи, спрямовані на регламентацію суспільних відносин. Це є акти індивідуалізованого правового регулювання і до таких він відносить судові рішення. На стадії реалізації він визначав акт реалізації як дію суб'єктів права по втіленню в життя приписів правових норм [17, c. 270]. Розуміємо, що і С.А. Новіков прагнув визначити передумови та підстави набуття суб'єктом адміністративного права статусу суб'єкта адміністративних правовідносин. У такому випадку передумовою $\epsilon$ наявність правової норми, яка містить елементи (гіпотезу та диспозицію), в яких нормативно визначено і особливості правового статусу суб'єкта адміністративного права, і умови, в яких він реалізовується, а підставою юридичний факт, з яким закон пов'язує виникнення, зміну чи припинення правовідношення. Оскільки мають місце різні площин відносин (відносини, які виникають за участі Головного сервісного центру МВС України), то для різних видів відносин властиві власні юридичні факти [16, с. 26].

Для виникнення адміністративно-правового статусу Головного сервісного центру МВС України необхідні норми, які б визначали такий статус та розпорядчий акт органу державної влади про створення такого органу у якості юридичної особи публічного права. Наразі таким актом і, 
відповідно, юридичним фактом є Постанова Кабінету Міністрів України «Про утворення територіальних органів 3 надання сервісних послуг Міністерства внутрішніх справ» від 28 жовтня 2015 р. № 889 [18], яким і було утворено Головний сервісний центр МВС. Наділення ж його повноваженнями відбулося на підставі Положення про Головний сервісний центр MBC, затвердженого Наказом Міністерства внутрішніх справ України від 07.11.2015 № 1393 [19], який прийнято відповідно до абзацу першого частини третьої ст. 13 Закону України «Про центральні органи виконавчої влади», Типового положення про територіальні органи міністерства та іншого центрального органу виконавчої влади, затвердженого Постановою Кабінету Міністрів України від 25 травня 2011 р. № 563, пункту 7 та підпункту 16 пункту 11 Положення про Міністерство внутрішніх справ України, затвердженого Постановою Кабінету Міністрів України від 28 жовтня 2015 р. № 878, Постанови Кабінету Міністрів України від 12 лютого 2020 р. № 79 «Деякі питання територіальних органів Міністерства внутрішніх справ» (розпорядчий акт органу державної виконавчої влади).

Оскільки Головний сервісний центр МВС України було створено як юридичну особупублічного права, нанього поширюється дія ЗаконуУкраїни «Про державну реєстрацію юридичних осіб, фізичних осіб - підприємців та громадських формувань», відповідно, моментом виникнення юридичної особи вважається момент внесення запису до ЄДРПОУ. Відповідний запис 3 ідентифікаційним номером (кодом ЄДРПОУ 40109173) було внесено 07.11.2015 р. та внесено інформацію щодо організаційно-правової форми: орган державної влади.

Другий підхід обгрунтовано Д.М. Бахрах, який ототожнює суб’єкта адміністративного права і суб'єкта адміністративних правовідносин, оскільки, на його думку, суб'єктами адміністративного права є всі учасники управлінських відносин, які адміністративно-правовими нормами наділені правами, обов'язками та здатністю вступати в такі правовідносини. Самі ж правовідносини у такому випадку є лише сферою реалізації приписів правових норм та сферою здійснення прав і виконання покладених на особу обов'язків [20, с. 41].

І.П. Голосніченко та Н.І.Золотарьова під суб'єктами адміністративного права розуміють учасників правовідносин, які мають суб'єктивні права та обов'язки, визначені нормами адміністративного права [21, с. 12].

Третій підхід було запропоновано О.В. Бачун, який $є$ протилежний першому. Автор вважає, що категорія «суб”єкт права» може вивчатись лише у контексті правовідносин, які ним породжені і в межах яких він існує [22, c. 9].

Погоджуючись з підходом O.I. Миколенко, що суб'єкт права як особа, що володіє правосуб'єктністю, може й не бути в певний момент учасником правовідносин, у тому числі й адміністративного процесу, проте в будь-якому випадку учасником правовідносин може бути лише суб'єкт права [23, c. 146-147], визначаємо, що насправді та протилежність категорій «суб”єкт адміністративного права» та «суб”єкт адміністративних відносин», яка була визначена I. Литвин, насправді $\epsilon$ доволі умовною. Адже йдеться про ті самі особи. Інша річ, що в теорії права усталеним є застосування категорії «учасник правовідношення». Вочевидь, що йдеться по одну й 
ту саму особу, але в контексті правовідношення, - як його учасника, яким може бути суб'єкт адміністративного права, наділений певними правами, обов'язками та відповідальністю, а якщо такий суб'єкт є суб'єктом владних повноважень - про його компетенцію та повноваження.

Звернувшись до теорії цивільного права, в якій традиційно розглядається інститут цивільного правовідношення, науковці, визначаючи його структуру, у якості елементів називають: учасників правовідносин (суб'єктів), об'єкти, права та обов'язки (зміст) [24, с. 33]. Притому, ст. 2 ЦК України учасниками цивільних відносин визначає фізичні особи та юридичні особи (далі - особи), державу Україна, Автономну Республіку Крим, територіальні громади, іноземні держави та інші суб’єкти публічного права.

Тобто, законодавець прямо визначив, що учасниками відносин є... суб'єкти публічного права.

Тим не менше, І. Литвин обгрунтовує позицію, що категорії «суб’єкт адміністративного права» і «суб'єкт адміністративно-правових відносин» не $є$ тотожними. Але в обгрунтування він наводить доводи щодо динаміки і статики, де в якості статики він розглядає суб'єкта адміністративних правовідносин, а динаміки - суб'єкта адміністративних правовідносин [25, c. 64]. Не можемо погодитися з таким підходом, адже не можна суб'єкта ототожнювати 3 процесом. Процес $є$ явищем. Суб'єктом $\epsilon$ певна особа, наділена правоздатністю та правомочностями. Адже ми не можемо визнавати Головний сервісний центр МВС України процесом. Він однозначно $є$ i суб'єктом, і учасником правовідносин. Цілком закономірно, що учасником правовідносин він $є$ з моменту вступу в конкретні правовідносини. Інша річ, про які відносини йдеться. Адже він перебуває в певних правовідносинах з МВС України та його структурними підрозділами, іншими органами державної виконавчої влади (вертикальні та горизонтальні зв'язки в межах публічної функції внутрішніх відносин системи органів публічної влади) та може вступати у відносини з особами приватного права (фізичними та юридичними особами) - замовниками адміністративних послуг як суб'єкт надання чи виконання адміністративних послуг, виконуючи публічносервісну функцію в межах своєї компетенції та наданих повноважень.

Визначення ж місця Головного сервісного центру МВС України в системі суб'єктів адміністративного права має важливе значення для встановлення особливостей його адміністративно-правового статусу. Пізнання правомочностей, кола функцій та повноважень цього суб'єкта, зумовлені його статусом та визначення місця в системі суб'єктів адміністративного права взаємопов'язані та взаємообумовлені: роль органу публічної влади у вирішенні питань, зокрема функцій держави, виконання окремих завдань, визначає і спрямованість діяльності такого органу, i, відповідно, його функції, компетенцію та повноваження. Таким чином, і пізнання елементів правового статусу такого органу, і системних (структурних) зв'язків Головного сервісного центру МBC 3 іншими суб'єктами в системі суб'єктів адміністративного права та визначення місця Головного сервісного центру МBC в такій системі - сприяють комплексному пізнанню адміністративно-правового статусу Головного сервісного центру МВС України. 
Нам імпонує підхід О.М. Музичука, який визначив, що елементи правового статусу (складники) у сукупності складають змістовну правову характеристику суб'єкта правовідносин, визначають його специфіку та відмінність від інших суб’єктів. Тому, на його думку, призначенням категорії «правовий статус» $є$ деталізація особливих ознак суб'єктів правовідносин. Він дав просте, але точне визначення, що у визначенні правового статусу суб'єкта адміністративних відносин основна увага має зосереджуватися на визначенні ролі та місця такого суб'єкта в системі правовідносин та визначенні відмінності цього суб'єкта від інших [26, c. 318-319].

Наразі класифікація суб'єктів адміністративного права була запропонована і Г.I. Петровим: а) громадяни, особи без громадянства та іноземці; б) органи державного управління та структурні підрозділи їх апарату; в) державні й громадські підприємства, установи та їх структурні підрозділи; г) органи громадських організацій, діяльність яких регулюється правом, та їх внутрішні підструктури; д) організації, які сприяють державному управлінню; е) службовці, які $\epsilon$ носіями адміністративних прав та обов'язків [27, с. 102]. Дещо відмінна від «традиційної» була запропонована класифікація О.А. Дьоміним, який поділив таких суб'єктів на юрисдикційні та ординарні, не даючи визначення цим категоріям суб'єктів [28, с. 23]. Вбачаємо, що різні класифікації суб'єктів адміністративного права були запропоновані різними науковцями за різними критеріями. Як бачимо, такими було запропоновано і повний перелік суб'єктів, і поділ на одинарні та колективні, і за критерієм характеру правового зв'язку (координації чи субординації), і за наявністю владних повноважень. Останній критерій класифікації було використано Н.В. Александровим та І.Б. Коліушко, які поділяли суб'єктів адміністративного права на: а) наділених владними повноваженнями; б) не наділених владними повноваженнями [29, с. 44].

Н.Ю. Хаманева та І.Л. Бачило визначили, що основними параметрами всіх державних органів, які визначають їх правовий статус є: призначення органу та його місце в системі органів виконавчої влади; легітимація цілі утворення органу, визначення сфери його функціонування, сфери суспільних відносин та, відповідно, сфери його діяльності; формулювання завдань і функцій органу державної виконавчої влади чи його структурного підрозділу; визначення змісту та характеру повноважень (прав і обов'язків) зі здійснення покладених завдань та функцій у певній галузі чи сфері його відання; наділення органу державної виконавчої влади чи його структурного підрозділу правом приймати відповідні правові акти; покладання обов'язку нести відповідальність за виконання повноважень органом державної влади чи його структурного підрозділу на такий орган, його керівника чи посадових осіб за порушення законодавства в діяльності такого органу чи його структурного підрозділу; визначення порядку формування його структури, штатів; визначення порядку та джерела фінансування, порядку ліквідації; нормування порядку прийняття, реалізації та контролю за виконанням рішень, інформаційне забезпечення органу виконавчої влади та його підрозділів тощо [319, c. 147-148]. 
Визначимо місце Головного сервісного центру МВС зазапропонованою нами класифікаційною схемою:

- за організаційно-правовою формою - $є$ органом державної влади;

- за зовнішньою відокремленістю - юридичною особою публічного права;

- за наявністю повноважень - суб'єктом, наділеним владними повноваженнями у сфері реалізації державної політики з забезпечення безпеки дорожнього руху та експлуатації транспортних засобів: $є$ суб’єктом, який безпосередньо реалізовує надані йому повноваження з метою забезпечення належного порядку управління; є органом державної виконавчої влади;

- за аксіологічним критерієм є первинним суб'єктом як орган публічної адміністрації, хоча $є$ підзвітним Міністерству внутрішніх справ України;

- за сферами виникнення та функціонування суб’єктів: суб'єктом публічного права.

Але така характеристика не дозволяє визначити а ні адміністративноправовий статус Головного сервісного центру МВС України, а ні його місце в системі суб'єктів адміністративного права.

Видається, що така характеристика $є$ видовим класифікатором, який, проте, не дозволяє зрозуміти предмет та сферу функціонування цього органу, його компетенцію та повноваження, які б ідентифікували та вирізняли його 3-поміж інших суб'єктів адміністративних відносин. Через нераціональність «подвійності»: покладання одних функцій на різні органи, - видається логічним, коли один орган державної влади виконує лише йому специфічні функції та завдання. Основні характеристики, які визначають місце Головного сервісного центру в системі суб'єктів адміністративного права $є$ : наявність владних повноважень, визначеність компетенції (через завдання та функції); визначеність владних, моніторингових, забезпечувальних, координаційних, представницьких та інших повноважень, в т.ч. повноважень з надання та координації та управління сервісною діяльністю МВС.

Водночас, Головний сервісний центр: не має власного майна, воно $€$ державною власністю і закріплюється за ним на праві оперативного управління; $\epsilon$ міжрегіональним територіальним органом 3 надання сервісних послуг Міністерства внутрішніх справ України; структуру ГСЦ МВС затверджує Міністр внутрішніх справ; наявність структурних підрозділів та відокремлених структурних підрозділів - регіональних сервісних центрів (РСЦ), які, в свою чергу, складаються зі структурних підрозділів, до яких, у тому числі, входять територіальні підрозділи - територіальні сервісні центри МВС (ТСЦ МВC); підзвітність та підконтрольність: регіональні сервісні центри підзвітні та підконтрольні керівництву Головного сервісного центру МВС.

Наразі існуюча структура виглядає фрагментарною та непослідовною. Перед Міністром внутрішніх справ відповідальним за забезпечення виконання публічно-сервісних функцій, які здійснюються територіальними сервісними центрами $\mathrm{MBC} \epsilon$ начальник Головного сервісного центру, притому, що це в той час, як а ні сам територіальний сервісний центр, а ні його начальник не $є$ підзвітними та підконтрольними 
а ні Головному сервісному центру, а ні його начальнику. Формально, згідно положень Положення про Головний сервісний центр МВС слідує наявність субординаційних зв'язків між Міністром внутрішніх справ та начальником Головного сервісного центру MBC та між Головним сервісним центром MBC та керівництвом регіональних сервісних центрів. Водночас, аналіз положень щодо завдання Головного сервісного центру MBC з організації діяльності РСЦ, здійснення контролю за їх діяльністю, надання їм організаційно-методичної і практичної допомоги та здійснення їх інформаційно-аналітичного, матеріально-технічного та фінансового забезпечення дає підстави для висновку, що вони мають, здебільшого, координаційний та забезпечувальний характер, аніж владно-розпорядчий. Вбачаємо, що подібна ситуація і з територіальними сервісними центрами. 3 метою усунення недоліків та протиріч правового регулювання в організації та здійсненні повноважень Головного сервісного центру МВС та територіальних сервісних центрів МBC, визначеності їх місця в системі суб'єктів адміністративного права, чіткості визначеності компетенції та повноважень у сфері публічно-сервісної діяльності, визначеності характеру владних зв'язків між ними (координації, субординації), вважаємо за необхідне запропонувати внести зміни та доповнення до законодавства в цій сфері, зокрема, п. 5 Розділу I Положення про Головний сервісний центр МBC, затвердженого Наказом Міністерства внутрішніх справ України від 07.11.2015 № 1393 [19] викласти в наступному формулюванні: «5. ГСЦ МВС організовує діяльність ТСЦ МВС, здійснює контроль за ними, надає їм організаційно-методичну і практичну допомогу та здійснює їх інформаційно-аналітичне, матеріально-технічне та фінансове забезпечення».

Висновки. Проведене дослідження дозволило визначити основні критерії та чинники, які визначають місце органу виконавчої влади, зокрема, Головного сервісного центру МВС в системі суб'єктів адміністративного права. Визначено, що він $\epsilon$ спеціалізованим органом виконавчої влади, який перебуває у підпорядкуванні Міністерства внутрішніх справ України, самостійною юридичною особою публічного права, за організаційно-правовою формою - спеціалізованим органом державної влади, який має власну компетенцію - забезпечення державної політики у сфері забезпечення безпеки дорожнього руху та безпеки експлуатації транспортних засобів, що має власну структуру: підпорядковані регіональні сервісні центри (статус територіальних сервісних центрів потребує уточнення і безпосереднього підпорядкування Головному сервісному центру MBC), 3 визначеними функціями та завданнями, та відповідними повноваженнями, серед яких основні: публічно-управлінські та публічно-сервісні, визначені Положенням про Головний сервісний центр МВС. Останні реалізовує шляхом надання публічно-сервісних послуг, безпосередньо надаваних територіальними відділеннями Головного сервісного центру, адміністративно-правове положення якого як адміністратора надання таких послуг потребує закріплення. 


\section{СПИСОК ВИКОРИСТАНИХ ДЖЕРЕЛ}

1. Воронятніков 0.0. Адміністративно-правовий статус державної міграційної служби України : автореф. дис. ... канд. юрид. наук : 12.00.07; ДВНЗ «Запоріз. нац. ун-т» МОНМС України. Запоріжжя, 2012. 17 с.

2. Дроздова I.В. Міністерство внутрішніх справ України, як суб'єкт надання адміністративних послуг : автореф. дис. на здобуття наук. ступ. канд. юрид. наук : спец. 12.00.07. Київ, 2009. 20 с.

3. Шуба В.В. Адміністративно-правові відносини в діяльності органів прокуратури України: загальнотеоретичні аспекти : дис. ... кандидата юрид. наук : спец. 12.00.07 Дніпропетровськ. держ. ун-т внутр. справ. Д., 2006. 200 c.

4. Мельник О.М. Адміністративно-правовий статус працівника митної служби: автореф. дис. к.ю.н. 12.00.07. Київ, 201118 с.

5. Ізотова М.О. Правовий статус керівника місцевої прокуратури : дис. к.ю.н. 12.00.10 Харків, 2018216 с.

6. Пустовіт 0.Ю.Адміністративно-правовий статус органів державного управління в галузі якості та безпечності сільськогосподарської продукції: дис. к.ю.н. 12.00.07 Київ, 2019. 211 с.

7. Мацелик Т.О. Суб'єкти адміністративного права: поняття та система : монографія. Ірпінь: Видавництво Національного університету державної податкової служби України, 2013. 342 с.

8. Дараганова Н.В. Дискусійні питання класифікації суб’єктів адміністративного права (на прикладі екіпажу повітряного судна України). Вісник НТУУ «КПІ». Політологія. Соціологія. Право. 2010. № 4-1. С. 227-232.

9. Курс адміністративного права України : підручник / В.К. Колпаков, О.В. Кузьменко, І.Д. Пастух та ін.]; за ред. В.В. Коваленка. Київ : Юрінком Інтер, 2012. 808 с.

10. Адміністративне право України : підручник / за заг. ред. д.ю.н., проф. Т.О. Коломоєць. Київ : «Істина», 2008. 500 с.

11. Стеценко С.Г. Адміністративне право України : навчальний посібник / Стеценко С.Г. Київ : Атіка, 2009. 640 с.

12. Загальне адміністративне право : підручник / [Гриценко I.С., Мельник Р.С., Пухтецька А.А. та інші]; за заг. ред. I.С. Гриценка. Київ : Юринком Інтер, 2015. 568 c.

13. Литвин I. Сутність системи суб'єктів адмінстартивно-правових відносин у сфері надання освітніх послуг. Підприємництво, господарство і право. 2016. № 15. С. 63-66.

14. Шуба В.В. Адміністративно-правові відносини в діяльності органів прокуратури України: загальнотеоретичні аспекти : дис. ... кандидата юрид. наук : спец. 12.00.07. Дніпропетровськ. держ. ун-т внутр. справ. Д., 2006. $200 \mathrm{c}$.

15. Авер'яновВ.Б. Адміністративне право України. Академічний курс: в двох томах. Київ : ТОВ «Видавництво «Юридична думка», 2007. Том 1: Загальна частина [підручник] / [ред. колегія: Авер'янов В.Б. (голова) та ін]. 592 с.

16. Новиков С.А. Административное право : конспект лекций. Москва : Приор-издат, 2003. 128 с. 
17. Теория государства и права. Учебник для юридических вузов и факультетов / под ред. В.М. Корельского и В.Д. Перевалова. Москва : Издательская група Норма-Инфра*М, 1998. 570 с.

18. Про утворення територіальних органів з надання сервісних послуг Міністерства внутрішніх справ: Постанова Кабінету Міністрів України від 28 жовтня 2015 р. № 889.

19. Про затвердження Положення про Головний сервісний центр MBC: Наказ Міністерства внутрішніх справ України від 07.11.2015 № 1393 (у редакції наказу Міністерства внутрішніх справ Українивід 26 листопада 2018 року № 955).

20. Бахрах Д.Н. система субъектов советского административного права. Советское государство и право. 1986. № 2. С. 41-48.

21. Голосніченко І.П. Адміністративне право України: основні поняття: навчальний посібник / Голосніченко І.П., Стахурський М.Ф., Золоторьова Н.I. / за заг. ред. доктора юридичних наук, професора I.П. Голосніченка. Київ : ГАН, 2005. 232 с.

22. Бачун О.В. Правовий статус суб'єктів адміністративного судочинства : монографія. Київ : Логос, 2009. 14 с.

23. Миколенко А.И. Административный процесс и административная ответственность: учеб. Пособие. Харьков: Одиссей, 2006. 351 с.

24. Цивільне право України : навчальний посібник : у 2 ч. Ч. 1 / за заг. ред. к.ю.н., проф. В.А. Кройтора, к.ю.н., доц. Кухарєва Є.О., к.ю.н., доц. Ткалича М.О. Запоріжжя : Видавничий дім «Гельветика», 2016. 384 с.

25. Литвин I. Сутність системи суб’єктів адмінстартивно-правових відносин у сфері надання освітніх послуг. Підприємництво, господарство і право. 2016. № 15. С. 63-66.

26. Музичук О.М. Уточнення сутності категорії «правовий статус» суб'єкта адміністративно-правових відносин та його елементного складу. Форум права. 2008. № 1. С. 316-321.

27. Петров Г.И. Советское административное право. Часть общая : учебное пособие. Ленинград : Изд-во Ленингр. ун-та, 1960. 344 с.

28. Демин А.А. Субъекты административного права Российской Федерации : учебное пособие. Москва : Книгодел, 2010. 272 с.

29. Основи адміністративного судочинства та адміністративного права / за заг. ред. Н.В. Александрової. Київ : Конус-Ю, 2006. 256 с.

30. Хаманева Н.Ю. Исполнительная власть в России. История и современность, проблемы и перспективы развития: К 80-летию Института государства и права РАН/ [Автономов А.С., Бачило И.Л., Бондаренко А.А. и др.]; отв. ред. Хаманева Н.Ю. Москва : Новая Правовая культура, 2004. 568 с.

\section{S. Petrov}

\section{LOCATION OF THE MAIN SERVICE CENTER OF THE MINISTRY OF INTERNAL AFFAIRS OF UKRAINE IN THE SYSTEM OF SUBJECTS OF ADMINISTRATIVE LAW}

The relevance of the article is that the need to determine the place of the Main Service Center in the system of administrative law is due to the need for division 
of competence between state executive bodies, determining the scope of powers necessary for effective performance of tasks before this body. The lack of in-depth theoretical developments and the guidance solely on the expediency of creating a new body for the provision of services in the system of the Ministry of Internal Affairs in practice has revealed many problems that need to be addressed. Among them - the complexity of the structure of subordination of regional and territorial service centers of the Ministry of Internal Affairs, and more precisely, the lack of such subordination of territorial service centers to the Main Service Center of the Ministry of Internal Affairs, determining the status of the Main Service Center and Regional Service Centers. The attempt to close this gap by recognizing regional service centers as branches of the Main Service Center has created an even greater problem in determining the administrative and legal status of territorial service centers, which is currently uncertain and positioned as structural units of the Regional Service Centers. The article examines the place of the Main Service Center of the Ministry of Internal Affairs in the system of subjects of administrative law. Approaches to determining the significance of the place of the state executive body in the system of subjects of administrative law are analyzed, and the effectiveness of the chosen structure of the service system of the Ministry of Internal Affairs of Ukraine is determined by the task set before the Main Service Center of the Ministry of Internal Affairs. It is proposed to improve such a structure and make changes and additions to the Regulations on the Main Service Center of the Ministry of Internal Affairs. The main criteria and factors that determine the place of the executive body, in particular, the Main Service Center of the Ministry of Internal Affairs in the system of subjects of administrative law. It is determined that it is a specialized executive body, which is subordinated to the Ministry of Internal Affairs of Ukraine, an independent legal entity under public law, in organizational and legal form a specialized body of state power, which has its own competence - ensuring state policy in road safety. and safety of operation of vehicles, which has its own structure: subordinate regional service centers, with certain functions and tasks, and relevant powers, among which the main: public administration and public service, defined by the Regulations on the Main Service Center of the Ministry of Internal Affairs.

Keywords: territorial service centers of the Ministry of Internal Affairs, competence, powers, rights and responsibilities, law enforcement agencies, legal personality, service activities, permitting activities, subjects of administrative law, administrative services. 